MARIUSz DEMBIŃSKI

ORCID 0000-0002-8352-5106

Uniwersytet im. Adama Mickiewicza

$w$ Poznaniu

\title{
WYCHOWANIE DZIECKA JAKO WYRAZ LUDZKIEJ TRAGEDII ${ }^{1}$
}

\begin{abstract}
AвSTRACT. Dembiński Mariusz, Wychowanie dziecka jako wyraz ludzkiej tragedii [Raising a Child as an Expression of Human Tragedy]. Studia Edukacyjne nr 55, 2019, Poznań 2019, pp. 93-107. Adam Mickiewicz University Press. ISSN 1233-6688. DOI: 10.14746/se.2019.55.6

Raising, reduced to the formula of up-bringing does not (Polish: wy-chowan-nie), allows us to reveal what is hidden, and by denying it (-not), it enables a person to experience the sense of his essence and see the tragedy of his upbringing and the sense of his life. Featured upbringing and up-bringing-does not (written separately) results from the difference in the approach to truth. Today, upbringing in its objectifying children truth refers to the concept of veritas, and because it lost its original meaning or aletheia, in search of the truth of upbringing, it was reduced to the formula of up-bringing-does not. With the help of this formula, an attempt was made to reveal the real sense of upbringing and the conditions that should be met in order for human up-bringing-does not to have a human (aletheia) dimension.
\end{abstract}

Key words: raising, wy-chowa-nie, aletheia, veritas, tragedy

Kogo wychowywać? Dzieci nie, ale wychowanie.

Mariusz Dembiński

\section{Wprowadzenie}

...wszyscy, którzy odstaniają tajemnice, mają tragiczne życie...

Anais $\mathrm{Nin}^{2}$

Pomimo że „Śmierć jest lepsza niż życie”3, jak powiedział Sokrates w Dia$\log u$ Platona Fajdros, to może i dlatego, gdyby mnie przed narodzinami za-

${ }^{1}$ Fragment niniejszego artykułu został wygłoszony podczas Ogólnopolskiej Konferencji Naukowej „Sytuacje stresowe dziecka w przestrzeniach życiowych dziecka”, która odbyła się 17 października 2018 r. w Poznaniu.

2 A. Nin, Dzienniki, przekł. B. Cendrowska, Poznań 2005, s. 205.

${ }^{3}$ Platon, Fajdros, przeł.. R. Regner, Warszawa 1993. 
pytano, czy chcę przebywać $\mathrm{w}$ świecie istot ludzkich, to z pewnością odpowiedziałbym: Nie, dziękuję. Człowiek, od początku swoich narodzin jest skazany na unicestwienie, a przy tym jego czasowa egzystencja przeniknięta jest niepokojem i lękiem o istnienie własne i najbliższych. Na domiar wszystkiego, $\mathrm{w}$ trosce pedagogicznej starszych pokoleń o młodsze zawiera się tragedia dziecięcego przebywania w świecie, w którym kreuje się miejsca dla realizacji potrzeb tych pierwszych. $W$ tych miejscach strach o własne istnienie $\mathrm{w}$ świecie ideologizuje się estetyką uetycznionej walki z własnymi słabościami wywiedzionymi zwykle $\mathrm{z}$ dzieciństwa, którymi - w fazie życia dorosłego - obwinia się podwładnych: w rodzinie własne dzieci, w szkołach uczniów, a w pracy współpracowników. Ujawniane zatem zestawy zachowań i postaw wskazują na etykę obarczoną brakiem estetycznej dojrzałości, którą intelekt usprawiedliwia, w duchu poczucia zachowania własnej racji. Zawierające się $\mathrm{w}$ tych postawach i zachowaniach uniwersum kalokagatii, które obejmuje piękno, dobro i prawdę, podlega egzystencjalnemu zatracaniu, stając się użyteczną poręką dla możliwości bycia nieuczciwym wobec siebie i innych. I jeżeli wychowanie staje się narzędziem kształtującej go edukacji, to musi służyć użytecznej poręce bycia nieuczciwym. W takiej sytuacji dramatem okazuje się samo życie, które wychowując do nieuczciwości, zatraciło swoją prawdę. A skoro prawda jest życiową nieprawdą, to i życie jest zafałszowaną prawdą.

W niniejszej wypowiedzi będę szukać odpowiedzi na pytanie, czy rzeczywiście wychowanie, sprowadzone do fenomenologicznej formuły wy-chowa-nie ${ }^{4}$, zawiera $\mathrm{w}$ sobie tragizm wpisujący się w egzystencjalny sens bycia człowiekiem-dzieckiem? Czy nie jest tak, że sens tej ludzkiej tragedii jest wynikiem cywilizacyjno-metafizycznego dążenia do zatracenia swojej prawdy, ujętej jako aletheia (nieskrytość) na rzecz veritas (odzwierciedlanie)? A może chodzi o uniemożliwienie pełnego ukształcenia się dziecka, zgodnie z jej naturalnym jestestwem, aby nie stanowiło zagrożenia dla siebie i innych? Zło, które nas otacza i którego jesteśmy nośnikami i twórcami, przynagla do refleksji i przyjrzeniu się wychowaniu. Czy czasami nie jest tak, że idealizujemy przestrzeń pedagogiczną $\mathrm{w}$ poszukiwaniu usprawiedliwienia dla bycia istotami niegodziwymi?

W tym tekście przyjmuję tezę, że wychowanie jako wy-chowa-nie, wy-dobywa na jaw w swoim socjalizującym odzwierciedlaniu (veritas) taki ukształcany (Bildung) obraz społecznej egzystencji, jaki uniemożliwia w swoim chowaniu ujawnienie się tego co nieskryte (aletheia), przy jednoczesnym zaprzeczaniu sobie - uzupełniając sens wychowania dopełnieniem: -nie. Oznaczać by to miało, że wychowanie uniemożliwia zobrazowanie swojej prawdy

${ }^{4}$ A.E. Szołtysek, w książce: Filozofia wychowania: ontologia, metafizyka, antropologa, aksjologia (Torun 1998), pisząc o wychowaniu, posłużył się formułą wy-chowanie, mając na uwadze wydobywanie na jaw tego, co chowane. 
poprzez zanegowanie: umożliwianiu. I jeżeli teza ta byłaby prawdziwa, to można powiedzieć, że wychowanie jako forma kształtująca "do" - „do bycia jakimś", uniemożliwia ujawnienie „od" - „od bycia jakimś”, gdzie „do" jest formułą do zrobienia i bycie jakimś, a "od" jest formułą "od-bycia” i bycia ja-kimś. Toteż niemożność bycia ja-kimśs staje się źródłem ludzkiej tragedii, jak w przypadku Antygony z tragedii Sofoklesa ${ }^{5}$.

\section{Pomiędzy przypomnieniem (wy-chowa-nie) a zapomnieniem (wychowanie)}

Jak dwa błądzace światy zetknęli się ze sobą na chwile $w$ nieskończonej przestrzeni, a teraz rozstawali się

Rolland Romain 6

Sformułowany temat niniejszej wypowiedzi wskazuje na wychowanie jako na oddziaływanie, w które wpisana jest tragedia zoperacjonalizowana konfliktem prowadzącym do przegranej, klęski, katastrofy, czy kompromitacji. Akt czy proces międzyludzkiego oddziaływania ma charakter historyczny, cywilizacyjny i w swojej wychowawczej strukturze podlegał takim ideom, jak: paideia ${ }^{7}$, Bildung ${ }^{8}, c^{2} y$ uczasowienie ${ }^{9}$, a obecnie mówi się o eduka$\mathrm{cji}^{10}$. Proces wychowawczego wpływania jednych ludzi na drugich jest czymś naturalnym, tylko problem polega na tym, że młody człowiek zostaje postawiony w sytuacji już dokonanej, bez możliwości wyboru, a tragedią i sarkastyczną komedią ludzkiego funkcjonowania w świecie okazuje się nie tyle źle pojmowana idea odpowiedzialności jednego człowieka za drugiego, ile zapomnienie prawdy wychowania, czyli przekształcenie sensu znaczenia wychowania na bazie alethei - veritas. Można przyjąć, że proces zapominania zaczął się w momencie zasadzenia przez człowieka rośliny, której zaczął poświęcać swoją uwagę. W ten sposób istota ludzka obok przyrody stała się twórcą, tworząc i rywalizując z naturą, by ostatecznie podporządkować ją sobie, między innymi poprzez ideologizację jej znaczenia, jako coś niedobre-

\footnotetext{
${ }^{5}$ Sofokles, Antygona, przekł. S. Hebanowski, Gdańsk 2003.

${ }^{6}$ R. Romain, Jan Krzysztof. Księga druga: Bunt. Targowisko, przekł. L. Staff, Warszawa 1989, s. 95.

7 W. Jaeger, Paideia. Formowanie człowieka greckiego, przekł. H. Bednarek, M. Plezia, Warszawa 2001.

${ }^{8}$ R. Horlacher, The Educated Subject and the German Concept of Bildung. A Comparative Cultural History, New York - London 2016.

9 P. Sosnowska, Arendt i Heidegger. Pedagogiczna obietnica filozofii, Kraków 2015.

10 Z. Kwieciński, Edukacja w galaktyce znaczeń, [w:] Pedagogika. Podręcznik akademicki, red. Z. Kwieciński, B. Śliwerski, Warszawa 2019, s. 43-53.
} 
go, ograniczającego człowieka i szkodzącego jego rozwojowi. Toteż i ludzkie wychowanie zatraciło swoje naturalne oblicze na rzecz bycia do zdrowienia.

Wychowanie, pisane bez myślników, jest formą zapomnienia, samo-zapominania, natomiast wy-chowa-nie, pisane z myślnikami, jest strukturą refleksywną (zwrotna praca myśli), która ma przypominać to, co jako wychowanie jest zapomniane. Wpisujący się - na bazie refleksywności - tragizm zapominania w sytuację wychowawczą, stanowi pewną presupozycję dookreślenia sensu i znaczenia analizowanego tutaj pojęcia, które dla swoich poznawczych, oglądowych i samo-wglądowych potrzeb zostało rozbite na trzy dopełniające się części, stanowiąc jej trójjednię, a pisaną jako wy-chowa-nie. W takim podejściu do wychowania chodzi o jej prawdę, jej pierwotne samostanowienie, czyli o wy-dobywanie na jaw tego, co chowane, co ukryte, z uwzględnieniem tego, co takiemu wychowaniu zaprzecza, jako jego dopełnienie, wyrażające się w słowie -nie, będące przy tym jego istotą.

Na pierwszy rzut oka, tego typu podejście do wychowania może wydawać się nader spekulatywne, a nawet absurdalne i dziwne. Jaki bowiem ma sens dążenie do odkrywania tego co zatajone, niewidoczne, a kiedy się tego dokona, to temu się zaprzecza!? Mimo wszystko ma to sens, ponieważ samo zaprzeczenie jest dlatego ważne, ponieważ przecząc sobie - na bazie podwójnej negacji - staje się możliwe dostrzeżenie jej istoty, a więc istoty samego wychowania.

\section{Inferencyjny model wychowania}

Sięgając (...) wstecz w życie rodziców, można dostrzec, jak ciosy niegdyś otrzymane oddają bezwiednie własnym dzieciom...

Jadwiga Cierniak ${ }^{11}$

Zastanawiając się nad sensem wychowania - pomijając nudne jego definicje - warto stwierdzić, że skutkuje nie tylko tym, w czym przyszło nam jako będącym dziećmi egzystować, ale także przekłada się na sens uobecniającego się przed każdym z nas świata, który ze sobą nosimy i który inferencyjnie nakładamy na te inne, przy spotkaniach z ludźmi. Inferencyjny zatem model wychowania, ujęte jako wy-chowa-nie, oznacza wydobywanie na jaw tego co ukryte i zwrotnie sobie zaprzeczając, w zaprzeczeniu którego zawiera się obrona własnej tożsamości (zachowanie swojego świata). W wychowaniu inferencyjnym wszelkie sytuacje pedagogiczne w osnowie społeczno-kulturowej do momentu wy-chowania podlegają oddziaływaniom odzwierciedlającym (veritas), aż do momentu pojawienia się "od”, "od-bycia” sobą, co skutkuje wyodrębnieniem się z - chowania (-chowanie) - nie, jako autoreflek-

${ }^{11}$ J. Cierniak, Człowiek sprzymierzeńcem czy wrogiem, Warszawa 1978, s. 98. 
sji - będącego refleksywnym wcieleniem się posiadanej tożsamości w byciu sobą. Brak negacji sprawia, że w wielu sytuacjach stajemy się "obiektami” manipulacji, nieraz sami przyjmujemy uległe postawy, na przykład wobec przełożonych w pracy, albo z natury poddajemy się wpływom tych, których urok nas fascynuje.

W wychowaniu inferencyjnym ściera się agogiczny wyznacznik prowadzenia. Wyznacznik ten w swojej wieloznaczności łączy w sobie takie pojęcia-mechanizmy, jak: ago - "prowadzić", agoge - „doprowadzić” z epagogo oznaczający „indukcję"12. Uściślając wy-chowa-nie sprowadzone do prowadzenia wydobywającego i negującego, pozwala nam widzieć w inferencji proces indukowania, który poprzez nakładanie się różnych „światów" - pedagogicznych oddziaływań doprowadza (agoge) jednostkę do wykształcenia własnej tożsamości - jako istoty uogólnionej, której prowadzenie (ago) jest zależne od niej samej. Oznacza to, że wychowanie staje się źródłem ludzkiej tożsamości, a ta $\mathrm{z}$ kolei decyduje o tym, na ile i w jakim stopniu daje się przyzwolenie oddziaływaniom wychowawczym, kształtującym, edukacyjnym. Idąc tym tropem jeszcze dalej, można stwierdzić, że ukształtowanie tożsamości warunkuje wolę - skoro tożsamościowo decyduje się o przyzwoleniu.

\section{Wy-chowa-nie jako trójjedni}

Czasem dobrze jest zaczać wszystko od początku.

Maxie Wander ${ }^{13}$

W swojej propozycji możliwego rozumienia wychowania wskazuję nie na przypominanie, ale na zapominanie. Wychowanie jako veritas zapomniało o alethei, a ta z kolei dąży do przypomnienia się poprzez wy-chowa-nie. Dzieląc zatem wychowanie na trzy jego składowe, na wy-chowa-nie, możemy mówić o trzech jego warstwach. Pierwszą tworzy przedrostek „wy-", który w swoim czasownikowym zestawie wykonuje określoną pracę, ukierunkowaną na osiągnięcie celu, w którym zapośrednicza się podstawę słowotwórczą, a mianowicie -chowanie. Przedrostek „,wy-", oznacza zatem tutaj coś, za pomocą czego, coś do czegoś się odnosi i podlega wy-dobywaniu. „Wy-" jest dodany do podstawy słowotwórczej, która stanowi drugą warstwę słowa wychowania i jest to pojęcie: „chować”. W Innym stowniku języka polskiego PWN"14 możemy odnaleźć jedenaście znaczeń tego pojęcia. Wczytując się $\mathrm{w}$ te dookreślenia i mając na uwadze wychowanie w ogóle, to chowanie przykładowo wskazuje na „,chowanie czegoś gdzieś" przez położenie tego w niewidocznym miejscu,

\footnotetext{
${ }^{12}$ W.K.C. Guthrie, Sokrates, przekł. K. Łapiński, S. Żakowski, Warszawa 2000, s. 130 i n.

${ }^{13}$ M. Wander, Dzienniki i listy, przekł. M. Skalska, Poznań 1987, s. 220.

${ }^{14}$ Inny stownik języka polskiego PWN, t. 1, red. M. Bańko, Warszawa 2000, s. 174.
} 
co pozwala nam traktować czynność wychowania jako „ukrywanie" na przykład w ludzkim umyśle tego, co się - jako „coś” - „do-" bytego skrywało.

$\mathrm{W}$ wychowaniu ujętym jako wy-chowanie zawiera się proces ujawniania tego, co ukrywa się w jednostce. Byłby to zatem taki proces, który opierając się na odzwierciedlaniu (veritas) dążyłby do do-słaniania, do-krywania, do-bywania, natomiast nawiązujący do nieskrytości (aletheia) miałby na uwadze od-słanianie, od-krywanie, od-bywanie, a w konsekwencji wy-dobywanie, które w tym ostatnim przypadku może stanowić nawiązanie do metody majeutycznej ${ }^{15}$, stosowanej przez Sokratesa w Dialogach Platona.

$\mathrm{W}$ takim razie, jak do tego stanowiska ma się trzecia warstwa słowa wy-chowan-nie, czyli „-nie"? Słowo to odsyła do przyrostka (końcówki fleksyjnej) -nie, który oznacza tutaj zaprzeczenie i wskazuje na negację tego, co ujawnia się w wyniku wy-dobywania jako do-słaniania (veritas). Taki punkt widzenia prowadzi do poglądu, z którego wynika, że wy-chowanie wy-dobywa to co chowane, ale w tym wydobywaniu jako odzwierciedlaniu zawiera się dosłanianie, skrywanie i dlatego ta forma wychowania nie ma nic wspólnego z prawdą.

Prawdą wychowania nie może być to, co wpisuje się w działanie wychowawcze, ale to, co jemu zaprzecza, to, co ukazuje się zza wy-dobywanego do-słaniania, zza wy-chowania. Oznaczać to powinno, że będąc od dziecka skazanymi na wychowanie, a przy tym z uwagi na wiek niezdolnymi do autorefleksji, gdzie wychowanie czyni nas nosicielami odzwierciedlającymi do-bycie w świecie, stając się jego elementami, to tragizm ludzkiej egzystencji polega na niemożności wyzwolenia się spod uwarunkowań świata, który jest imitacją rzeczywistości, bo ta oprócz zasłaniania nie ma nic wspólnego z rzeczywistością.

I choć teraz $\mathrm{w}$ mojej pamięci pojawiło się skojarzenie $\mathrm{z}$ alegorią jaskini Platona, to wy-chowa-nie dopełnione -nie, staje się poręką umożliwiającą do-bycie prawdy o swoim bycie. I dlatego „-nie” w swoim zaprzeczeniu stanowi przypomnienie o zapomnieniu, o nieskrytości.

\title{
Zapomnienie nieskrytości wychowania
}

\author{
Aby odpowiedzieć na pytanie, \\ jaki jest świat, jaki nas ukotysat i uksztattowat \\ trzeba ten świat utracić. \\ Ryszard Chodźko ${ }^{16}$
}

Tragedią wychowania, a tym samym tragedią wychowywanych jest zagubienie kształtowania do bycia autentycznym. I aby zrozumieć sens tego

${ }^{15}$ G. Reale, Historia filozofii starożytnej, t. 1, przekł. E.I. Zieliński, Lublin 2000.

${ }^{16}$ R. Chodźko, Wyobraźnia wyzwolona. Rzeczywistość osoby i nierzeczywistość doktryny, Białystok 1992, s. 34. 
zagubienia, należy sięgnąć do pojęcia prawdy i różnicy ontycznej zapośredniczonej z jednej strony w greckim słowie aletheia, a z drugiej strony - w łacińskim wyrazie veritas.

Różnica ta, w przypadku aletheia ${ }^{17}$ odnosi się do nieskrytości, a więc do tego, co jest jako będące nie-skrywającym się; jest czymś oczywistym, powszechnie zrozumiałym i nie wymaga wyjaśnień, a co charakterystyczne - nie podlega interpretacji. Należy zauważyć, że tak pojętą prawdę wywodzi się ze starogreckiego słowa a-letheia, które jednocześnie wskazuje na odkrywanie i zasłanianie, na nieskrytość i skrytość, a więc nie wpisuje się ono w myślenie logiczne oparte na prawdzie lub fałszu, ponieważ nie zawiera w sobie negacji, nie-prawdy. A-letheia to, w czym się przejawia, w czym się istoczy, naznacza prawdą. Dlatego, będąc schowaną w wychowaniu, nie czyni wychowanie prawdą nieskrytości, co więcej - w swoim przymusowym zaprzeczeniu, sprowadzonym do przyrostka -nie, „nie” jest krzykiem skrytości - letheia, że może być nieskryte - a-letheia.

Z kolei veritas, jak stwierdza M. Heidegger, jest wytworem cywilizacji europejskiej opartej na metafizyce i można dodać - kontynuacją zrytualizowanej formy myślenia magicznego ${ }^{18}$. W tym myśleniu, poznanie zwymiarowane kategoriami jest sprowadzone do światoobrazów ${ }^{19}$, w przedstawieniach których odzwierciedla się prawda logiki i racjonalizm wymyślanych znaczeń „pozamykanych” w symbolach. W ten sposób metafizyka podporządkowała sobie: po pierwsze - naukę, która przekształca wszelką praktykę w technikę, po drugie - kulturę, której wartości z uwagi na ich opiekuńczy (zideologizowany) charakter mają wymiar polityczny, po trzecie - wyznania i odbóstwianie świata, które prowadzą do zawieszenia sensu wiary i po czwarte - sztukę, która w swojej estetyce stała się czymś, co się przeżywa, będąc przy tym wyrazem sposobu ludzkiej egzystencji. Oznacza to, że metafizyka stała się źródłem i sposobem europejskiego postrzegania świata, nastawionego na tworzenie modeli reprezentacyjnych ${ }^{20}, \mathrm{w}$ których prawdą (veritas) było to, co prowadziło do zgodności rzeczy z intelektem. Veritas, konstytuując zatem różne teorie, koncepcje, doktryny i tym podobne natury filozoficzno-pedagogiczne, zwymiarowane współcześnie edukacją, w sposób niejednoznaczny „wymyślają" poglądy pedagogiczne, w których poprzez wychowanie nie można dostrzec niemetafizycznej prawdy. Nie można tego uczynić, po pierwsze dlatego, że altheia jest chowana przez veritas, poprzez jej działanie będące

${ }^{17}$ M. Heidegger, Aletheia, przekł. J. Mizera, [w:] Tenże, Odczyty i rozprawy, Kraków 2002, s. 229-152.

${ }_{18}$ M. Dembiński, Ramy pedagogiki, Poznań 2015, s. 17-32.

${ }^{19}$ M. Heidegger, Czas światoobrazu, przekł. K. Wolicki, [w:] Tenże, Budować, mieszkać, żyć. Eseje wybrane, Warszawa 1977.

${ }^{20}$ P. Beart, F. Carreira da Silva, Teorie społeczne w XX wieku i dzisiaj, przekł, S. Burdziej, Kraków 2013. 
kreacją do-słaniającą to, co wy-dobywa, a po drugie dlatego, ponieważ to, co jawi się jako aletheia jest jednocześnie skrywane i nieskrywane - nie podpada pod myślenie logiczne, a więc nie może być zanegowane i tym samym nie musi spełniać ontologicznych i epistemologicznych warunków stanowiących o reprezentacji. Brak negacji w aletheia, w kontekście veritas, staje się źródłem zapominania, do-słaniania. $\mathrm{Z}$ tego to względu, samo zapomnienie nie wynika ze świadomego działania - jest rezultatem braku możliwości ukazywania prawdy bez do-słaniania.

\section{Nastrojone wy-chowa-nie w ekstasis}

W(...) godzinach, które z głębi zapomnienia przywołuję ku sobie, nietknięta pozostała pamięć czystego wzruszenia chwila zawieszona w wieczności.

Albert Camus ${ }^{21}$

Wychowanie, które sprawia, że dziecko staje się ja-kieś, jest - idąc tropem przywołanego już tutaj M. Heideggera - zabarwione nastrojami ${ }^{22}$, które należy rozumieć jako odczuwane przez każdego człowieka przeżycia, pojawiające się w każdej sytuacji życiowej. Samo zaś odczuwanie dopełnia się poprzez wydarzanie siebie $w$ myślącym nastrojeniu, albowiem - jak stwierdza M. Heidegger - bycie w swoim życiowym dawaniu oferuje nastrojenie. Podstawowym nastrojeniem (Grundstimmung) jest zdziwienie (Erstaunen), które otwiera zapytanie domagające się wiedzy. M. Heidegger pisze: „Tego rodzaju nastrój, w którym komuś «jest» tak lub inaczej, pozwala nam - gdy jesteśmy nim przeniknięci - znaleźć się wśród bytu w całości".

Wychowanie ujęte w swoim nastrojeniu sprawia, iż pojawia się możliwość od-słonięcia samego siebie. W od-słanianiu człowiek zwraca się ku temu, co ujawnia się jako wy-chowa-nie i w tym wariancie wychowania, doświadczaną sytuacją jest nastrajane przez jego dopełnienie, czyli -nie. Oznacza to, że uaktywnia się możliwość doświadczenia swojej prawdy istnienia, ale pod warunkiem jeśli prawda ta wyłania się na sposób ekstatyczny, czyli poprzez przekraczanie siebie, czy też wystawanie z siebie, co należy wiązać z greckim pojęciem ekstasis.

Ekstasis (gr. ع̌́кotaoıs) oznacza „bycie lub stanie poza sobą”, a także „wy-stawanie". Wy-stawanie wpisując się w wy-chowa-nie umożliwia od-słanianie, uniemożliwiając - jak pisze Alphonso Lingis ${ }^{23}$ - rozproszenie własnej toż-

\footnotetext{
${ }^{21}$ A. Camus, Eseje, przekł. J. Guze, Warszawa 1971, s. 60.

${ }^{22}$ M. Heidegger, Bycie i czas, przekł. B. Baran, Warszawa 1994, s. 190-194.

${ }^{23}$ A. Lingis, The Imperative. Studies in Continental Thought, Bloomington 1998.
} 
samości, która pojawia się $\mathrm{w}$ takich stanach zawieszenia, jakie przykładowo pojawia się w stanie liminalnym rytuału przejścia ${ }^{24}$.

Ekstasis dzięki zaprzeczeniu - nie w wy-chowa-niu podlega metanoi, czyli przemianie duchowej, która umożliwia cielesne przekraczanie siebie, wy-stawiając się - niejako w płaszczyźnie mentalnej - do współistnienia z innymi, ale na zasadach, nie odtwarzania rzeczywistości (veritas), ale jej stwarzania (aletheia). Samo bowiem wy-stawianie jest takim sposobem bycia, który stanowi nastrojenie do działania od-słaniającego to, co $\mathrm{w}$ rezultacie pojawia się w świecie rzeczywistym jako jego novum, czy bycia innym/różnym od tego, co w nim zastane.

Sposób wy-stawiania się ludzkiego bytu stanowi jego istotę, gdzie „Istotą tego bytu - jak pisze M. Heidegger - jest egzystencja" ${ }^{25}$. W niej zawiera się nasz sposób funkcjonowania w świecie, a jego prawdę możemy odkryć poza jego granicami. Niemniej, jesteśmy istotami z tego świata i z punktu widzenia wychowania oznacza to tyle, iż zanim zacznie się ono istoczyć, dziecko, człowiek musi najpierw wkroczyć w sytuację wychowawczą, aby ją móc wychowawczo przekroczyć - i nie chodzi tutaj o to, aby w niej chwilowo zaistnieć, ale o to, aby ona w nim się pojawiła i tak zaistniała, że będzie w niej z siebie wy-kraczać. Dlatego istota bycia człowiekiem, która jest jego egzystencją, musi być czymś stałym i niezmiennym, a to dlatego, że człowiek powinien mieć możliwość przekraczania siebie; transcendować, wy-stawić $\mathrm{z}$ siebie - będąc ucieleśnionym nie tyle z materią świata, ile z formą własnego ciała, którą - idąc tropem fenomenologii radykalnej - należy sprowadzić do cielesności (la chair) ${ }^{26}$. Cielesność to nastrojone wewnętrzne doznania, to "pre-refleksyjność" nazwana również „żywą tkanką cielesności.

Ludzkie ekstasis, wpisując się w wy-chowa-nie ucieleśnia się w jego zaprzeczeniu jako możliwość wydarzania się siebie, dzięki czemu człowiek może poczuć istotę swojej egzystencji - ucieleśnienie prawdy (aletheia). Dzięki ekstasis możemy znaleźć się na zewnątrz siebie, będąc tożsamy w sobie wobec Innego pozostającego $\mathrm{w}$ świecie rzeczywistym ( $\mathrm{w}$ świecie prawdy veritas) i dlatego nigdy nie uda nam się dotrzeć do Innego będąc na zewnątrz siebie. Emmanuel Levinas stwierdza, że: „...ekstaza, czyli zewnętrzna wobec Innego, na zawsze pozostaje poza wszelką próbą pełnego schwytania; ta inność jest niekończącą się lub nieskończona" ${ }^{27}$. Ta różnica jest różnicą epistemologiczną i dlatego człowiek znajduje się w tragicznej sytuacji. Czy to oznacza, że człowiek istocząc się w wychowaniu jest skazany na wieczne utrapienie?

\footnotetext{
${ }^{24}$ V. Turner, Proces rytualny. Struktura i antystruktura, przekł. E. Dżiurak, Warszawa 2010.

${ }^{25}$ M. Heidegger, Bycie i czas, s. 298.

${ }^{26}$ M. Merleau-Ponty, Widzialne i niewidzialne, przekł. M. Kowalska, J. Migasiński, R. Lis, I. Lorenc, Warszawa 1996, s. 269.

27 E. Levinas, Le temps et l'autre, Paris 1991, s. 8.
} 


\title{
Po-ręczność wychowania i wy-ręczność wy-chowa-nie ${ }^{28}$
}

\author{
Przytulmy dzieci, żeby w przyszłości, w chwili naszego przemijania \\ objęty nas ich ręce i przeniosty w inny byt.
}

John Maxwell Coetzee ${ }^{29}$

Aby rozstrzygnąć powyższe pytanie, spróbujmy sięgnąć do poręczności wychowania, poprzez którą wychowanie powinno ujawnić swój narzędziowy charakter czy narzędziową przydatność/skuteczność w swoim przeznaczeniu.

Człowiek przebywając w świecie, w otoczeniu światowości - idąc tropem M. Heideggera ${ }^{30}$ - doświadcza siebie, swoje w nim realne istnienie (Dasein) dzięki temu, że bytuje w nim w określony sposób. Sposób ten nie oznacza obecności, ale funkcjonowanie w czymś, co tym czymś - dla nas - będzie wychowanie. Sprowadzenie realnego istnienia człowieka w świecie do obecności sprawia, że jest postrzegany jako przedmiot. Taki zarzut można sformułować na przykład wobec Edmunda Husserla, który w duchu europejskiej metafizyki stwierdził, że rzeczy naszego świata są nam dane na sposób przed-ręczny (vorhenden) ${ }^{31}$. Jak pisze Wawrzyniec Rymkiewicz: „Takie utożsamienie obecności z przedmiotowością wynika z przekonania, że podstawowym sposobem naszego kontaktu ze światem jest poznanie" ${ }^{\prime \prime 2}$. I jeżeli wychowanie jest tym, co w sposób przed-ręczny pojawia się przed pedagogiem, to sprowadzenie wychowania do przedmiotu pedagogiki jest właśnie przykładem uczynienia z pedagogiki formy poznania, która umożliwia kontakt z drugim człowiekiem poprzez sprowadzenie go do przedmiotu, co w sytuacji wychowawczej oznacza, że bycie obecnym w świecie w swoim ukształcalnym poznaniu ma rzeczowo-przedmiotowy wymiar i dlatego drugiego człowieka sprowadza się do przedmiotu, do rzeczy, do tego, co ma się przed-ręką i warunkuje jego poznanie. Wyłaniająca się tutaj sytuacja wychowawcza jest co jedynie wglądowym oglądaniem przez zaangażowanych w tę sytuację tego, co się w niej dzieje; jest tym, w co się wkracza i co zamyka się przed transcendencją. Zakłada się bowiem tutaj w sposób wyidealizowany, że człowiek, dziecko w swoim rozumiejącym, a nawet przedrozumiejącym poznaniu, wspartym socjalizującą iteracją (powtarzaniem), osiągnie takie predyspozycje, że w swojej przed-ręczności będzie umiał usytuować się w „przed” -ręczności i poznawczo w swojej (z)ręczności działać w świecie. W tak pojętej sytuacji

${ }^{28}$ Piszę wy-chowa-nie zamiast wychowania, aby zachować negację w tej propozycji jego rozumienia.

${ }^{29}$ J.M. Coetzee, Wiek żelaza, przekł. A. Myslowska, Kraków 2004, s. 7.

${ }^{30}$ M. Heidegger, Bycie $i$ czas, s. 89-94.

${ }^{31}$ M. Waligóra, Wstęp do fenomenologii, Kraków 2013.

32 W. Rymkiewicz, Ktoś i Nikt. Wprowadzenie do lektury Heideggera, Wrocław 2002, s. 83. 
wychowawczej dziecko samo $\mathrm{w}$ sobie, na miarę własnego rozumienia i poznania w sposób światoobrazowy ${ }^{33}$ jest skazane na radzenie sobie z własnymi słabościami, strachem, niepokojem, stresem.

Dla M. Heideggera ${ }^{34}$ bycie $\mathrm{w}$ świecie nie może się ograniczać do jego poznawania, lecz jest wyrazem zatroskania, niepokoju. Prezentujące się w świecie rzeczy-przedmioty są zorientowane na działania praktyczne. Albowiem to, co w swojej obecności się prezentuje, nie pojawia się w obszarze poznającego rozumu, lecz $\mathrm{w}$ roztropnej przezorności, pobudzając zatroskanie. $\mathrm{W}$ roztropnej przezorności rzeczy i przedmioty pojawiają się jako narzędzia, w odnoszeniu do których nie chodzi o to, czym są, tylko o to, w jaki sposób się uobecniają, prezentują. Narzędzia zatem w swojej prezentacji zawsze przedstawiają się i dlatego nie są czymś przed-ręcznym, ale po-ręcznym, do-ręcznym ${ }^{35}$. Ich stosowanie ujawnia ich sens, który jednocześnie jest wyrazem zindywidualizowanego zachowania. Dopóty, dopóki narzędzie jest użyteczne, jest niezauważalne, skryte. Dopiero kiedy zaczynają się problemy, narzędzia zaczynają się uobecniać. Ich obecność pobudza zatroskanie.

Jak zatem będzie prezentować się wychowanie jako po-ręczność? Narzędziowy charakter wychowania (pisany łącznie) nie wyklucza sytuacji wychowawczej czy edukacyjnej oraz obecności w niej rodzica czy nauczyciela. Bycie-w-świecie w sposób pierwotny zakłada współobecność innych ludzi, z którymi można się komunikować. Użyteczność rzeczy jest wszystkim dana i to ona wskazuje na jednostki jako ich "posiadaczy", , dostawców" czy „producentów”. Takie podejście do ludzkiej egzystencji czyni wychowanie, a konkretnie pedagogikę zakładnikiem życia społecznego współistnienia. Na przykład, uczeń uzyskując jakiś „materiał” edukacyjny od nauczyciela, musi nabyć taką umiejętność, aby w swoim użytecznym działaniu tworzył to, co będzie edukacyjnie użyteczne. Otrzymując coś „od kogoś”, należy to tak przekształcić, aby to coś było „dla kogoś". Tak pojęta użyteczność uprzedmiatawia kształcących poprzez swoje technologiczne umasowienie edukacji i dlatego współistniejąc z innymi, wykształceni w każdym momencie mogą być wymienieni przez innych. Społeczny wymiar ludzkiego współistnienia jest zatem również wyrazem ludzkiego dramatu, niepokoju w swoim zindywidualizowanym zatroskaniu o swoją przyszłość.

Wracając do sytuacji wychowawczej czy edukacyjnej, wspomniano wcześniej, że dziecko w swoim ekstasis przebywającego prze-kraczania świata, może podpadać pod wy-chowa-nie. Taka sytuacja nie pojawi się wówczas, jeżeli wychowywany w sposób bezrefleksyjny funkcjonuje w świecie, ponieważ rozumie sens bycia narzędzia i potrafi nim bezproblemowo się posługiwać.

\footnotetext{
${ }^{33}$ M. Heidegger, Czas światoobrazu.

${ }_{34}$ M. Heidegger, Bycie $i$ czas, s. 80 i n.

35 Tamże, s. 100-102.
} 
W sytuacji, kiedy pojawią się problemy, użyteczna efektywność narzędzia zaczyna budzić zastrzeżenia i wówczas użytkownik wychowania zaczyna mieć problemy ze zrozumieniem jego istoty i sensu; nie potrafi ustosunkować się do możliwości, które świat w sobie oferuje.

Związek pomiędzy narzędziami - zauważmy [pisze W. Rymkiewicz - M.D.] - ma charakter możliwości: odnosząc coś do czegoś i coś po coś robiąc wyznaczam, projektuję, a następnie realizuję możliwości rzeczy użytkowych. Świat jest więc pierwotnie obecny tak, jak obecne są możliwości. I dopiero w ramach tak obecnego świata spotykamy „naturę": rzeczy, które są po-nic i które często utrudniają nam realizację naszych projektów ${ }^{36}$.

W spotkaniu $\mathrm{z}$ „naturą" po-ręczność rzeczy staje się bezużyteczna, toteż odsłaniające się wy-chowa-nie w swojej negującej po-ręczności to, co w swoim użytecznym wy-dobywaniu chowa, będąc do-słaniane, staje się narzędziem, które staje się użyteczne w swojej prawdzie w jej wy-ręczności. Chodzi tu o to, że prawda wychowania jako wy-chowa-nie pojawia się w wy-stawaniu (ekstasis) poza ten świat. To „wy” w wy-stawaniu jest tym, co w swojej prawdzie nie potrzebuje bycia po-ręcznym - $\mathrm{w}$ alethei, prawda sama $\mathrm{z}$ siebie się wy-stawia i tym samym jest czymś wy-ręczonym, wyręczającym - samoobjawiającym się.

\section{Poza pułapką wychowania - podsumowanie}

...żeby wydostać się z labiryntu, trzeba przejść po nim górą.

Angela $\mathrm{Carter}^{37}$

Wydaje się, że poglądy E. Husserla, ale i M. Heideggera na temat narzędziowego bycia człowieka w świecie w znaczący sposób wpisują się w obecną nam rzeczywistość. Komercjalizacja ludzkiego myślenia, jego socjalizowanie wraz ze wzrostem biurokratyzacji ludzkiej egzystencji w osnowie jej technologizacji przekłada się na uprzedmiotawiane sensy bycia człowiekiem zwymiarowane użytecznością wychowania. Nie oznacza to, że powyższe stanowisko ma charakter uniwersalny i każda forma wychowania ma tylko i wyłącznie charakter po-ręczny. Na przykład, można mieć tutaj na uwadze takie koncepcje pedagogiczne, w których kształtowanie dziecka w jego egzystencji odnosi się do jego strefy najbliższego rozwoju ${ }^{38}$, w której mocą sprawczą będzie nie tyle poczucie troski, ile uwrażliwienie nastawio-

\footnotetext{
${ }^{36}$ W. Rymkiewicz, Ktoś i Nikt, s. 87.

37 A. Carter, Magiczny sklep z zabawkami, przekł. M. Świerkocki, Warszawa 1999, s. 195.

${ }^{38}$ L.S. Wygotski, Wybrane prace psychologiczne, przekł. E. Flesznerowa, J. Fleszner, Warszawa 1971; tenże, Wybrane prace psychologiczne. Dzieciństwo i dorastanie II, przekł. A. Brzezińska i in., Poznań 2002.
} 
ne na cielesność. Pomagając dziecku poprzez kształtowanie uwrażliwienia, konstruuje się rusztowanie ${ }^{39}$ współpracy poprzez realizację zadań do samodzielnego wykonania, co daje dziecku możliwość nadawania sobie określenia ${ }^{40}$. Przykłady edukacji kładące nacisk na upodmiotawianie dzieci można by mnożyć, choć wiele $\mathrm{z}$ nich nie spełnia kryterium zaprzeczenia -nie w wychowaniu. Pomijając te podejścia, to tragedią wychowania jest fakt zagubienia jej prawdy, przez co dziecko jest skazane na socjalizujące i uprzedmiotawiające je oddziaływania społeczne, do których poznawczo, refleksyjnie, a więc poprzez istotę swojego bycia nie może w sposób „aletheiczny", czyli nieskryty się odnieść; nie może, ponieważ w swoim wy-chowaniu jest pozbawione -nie, ujęte jako wy-chowa-nie. Dlatego należy dążyć do uczynienia z wychowania narzędzia, za pomocą którego będzie można przekroczyć, $w y$-kroczyć poza swoje bycie. Stanie się to możliwe dzięki rozbudzaniu w dziecku refleksyjnego namysłu ukierunkowanemu ku wy-dobywaniu na jaw tego, co w jego wychowaniu jest do-słaniane (ideologizowane, replikowane, indoktrynowane, marginalizowane itp.), by w konsekwencji móc w swojej negacji siebie dostrzec swoją prawdę - prawdę swojego bycia.

Nie sposób pozbawić się prawdy świata, w którym żyjemy. Sposób wychowania, który jest podporządkowany veritas, stał się dramatyczną - w swojej niewiedzy - formą sposobu doświadczania siebie. Dziecko, doświadczając siebie poprzez wychowanie, jest nastawione na poznanie i kształtowanie swojej tożsamości w obliczu odzwierciedlania, które czyni je bezrefleksyjnym naśladowcą. Powiemy, że staje się mimetyczną formą istnienia. Poprzez wy-chowanie, które wydobywa na jaw, zasłaniając to, co chowane, został skazany na brak przeciwstawiania się sobie, na zapomnienie o swojej istocie. Dlatego wy-chowa-nie jest tym narzędziem poznania, które w swojej rzeczywistej wy-ręczności umożliwia ludzkiej ek-sistencji przekraczać (negować) siebie, by zwrócić się ku prawdzie. Człowiek zatem za sprawą swojej wy-ręczności może postawić się w sytuacji zwrotnego momentu jego życia, w czymś, co w grece określa się jako kairos i co powinno stać się źródłem doświadczania przez niego katharsis, prowadzącego do metanoi - przemiany. Toteż z uwagi na możliwość przemiany nie bez znaczenia staje się wypowiedź B. Suchodolskiego, który pisze:

Dla pedagoga człowiek nie jest takim jakim jest, lecz jest zawsze takim, jakim się staje pod wpływem wychowania, a nawet nie jest tym kim jest, lecz tym, kim mógłby być, gdyby zostały dopełnione warunki jego wzrostu i przemian ${ }^{41}$.

${ }^{39}$ J.S. Bruner, Kultura edukacji, przekł. T. Brzostowska-Tereszkiewicz, Kraków 2006.

${ }^{40}$ D. Benner, Pedagogika ogólna: Wprowadzenie do myślenia i działania pedagogicznego w ujęciu systemowym i historyczno-problemowym, przekł. D. Stępkowski, Warszawa 2015.

${ }^{41}$ B. Suchodolski, Pedagogika, [w:] Encyklopedia pedagogiczna, red. W. Pomykało, Warszawa 1993, s. 539. 
Wychowanie prowadzi do przemiany. Uczyńmy z niego właściwy użytek, nie dopuszczając, by stał się narzędziem serwisu - narzędziem wymiany.

\section{BIBLIOGRAFIA}

Beart P., Carreira da Silva F., Teorie społeczne w XX wieku i dzisiaj, przekł. S. Burdziej, Wydawnictwo Nomos, Kraków 2013.

Benner D., Pedagogika ogólna: Wprowadzenie do myślenia i działania pedagogicznego w ujęciu systemowym i historyczno-problemowym, przekł. D. Stępkowski, Wydawnictwo Uniwersytetu Kardynała Stefana Wyszyńskiego, Warszawa 2015.

Bruner J.S., Kultura edukacji, przekł. T. Brzostowska-Tereszkiewicz, Universitas, Kraków 2006.

Camus A., Eseje, przekł. J. Guze, Państwowy Instytut Wydawniczy, Warszawa 1971.

Carter A., Magiczny sklep z zabawkami, przekł. M. Świerkocki, Prószyński i S-ka, Warszawa 1999.

Chodźko R., Wyobraźnia wyzwolona. Rzeczywistość osoby i nierzeczywistość doktryny, Wydawnictwo Nowa Era, Białystok 1992.

Cierniak J., Człowiek sprzymierzeńcem czy wrogiem, Wiedza Powszechna, Warszawa 1978.

Coetzee J.M., Wiek żelaza, przekł. A. Myslowska, Wydawnictwo Znak, Kraków 2004.

Dembiński M., Ramy pedagogiki, Zakład Graficzny UAM, Poznań 2015.

Guthrie W.K.C., Sokrates, przekł. K. Łapiński, S. Żakowski, Wydawnictwo Aletheia, Warszawa 2000.

Heidegger M., Czas światoobrazu, przekł. K. Wolicki, [w:] Tenże, Budować, mieszkać, żyć. Eseje wybrane, Warszawa 1977.

Heidegger M., Bycie i czas, przekł. B. Baran, PWN, Warszawa 1994.

Heidegger M., Aletheia, przekł. J. Mizera, [w:] Tenże, Odczyty i rozprawy, Wydawnictwo Baran i Szuszczyński, Kraków 2002.

Horlacher R., The Educated Subject and the German Concept of Bildung. A Comparative Cultural History, Routledge, New York - London 2016.

Inny Stownik Języka Polskiego PWN, t. 1, red. M. Bańko, Wydawnictwo Naukowe PWN, Warszawa 2000.

Jaeger W., Paideia. Formowanie człowieka greckiego, przekł. H. Bednarek, M. Plezia, Fundacja Aletheia, Warszawa 2001.

Kwieciński Z., Edukacja w galaktyce znaczeń, [w:] Pedagogika. Podręcznik akademicki, red. Z. Kwieciński, B. Śliwerski, Wydawnictwo Naukowe PWN, Warszawa 2019.

Levinas E., Le temps et l'autre, Presses universitaires de France, Paris 1991.

Lingis A., The Imperative. Studies in Continental Thought, Indiana University Press, Bloomington 1998.

Merleau-Ponty M., Widzialne i niewidzialne, przekł. M. Kowalska, J. Migasiński, R. Lis, I. Lorenc, Fundacja Aletheia, Warszawa 1996.

Nin A., Dzienniki, przekł. B. Cendrowska, Zysk i S-ka, Poznań 2005.

Platon, Fajdros, przekł. R. Regner, Warszawa 1993.

Reale G., Historia filozofii starożytnej, t. 1, przekł. E.I. Zieliński, RW KUL, Lublin 2000.

Romain R., Jan Krzysztof. Księga druga: Bunt. Targowisko, przekł. L. Staff, Polska Spółdzielnia Wydawnicza, Warszawa 1989.

Rymkiewicz W., Ktoś i Nikt. Wprowadzenie do lektury Heideggera, WUW, Wrocław 2002. 
Sofokles, Antygona, przekł. S. Hebanowski, Wydawnictwo słowo/obraz terytoria, Gdańsk 2003.

Sosnowska P., Arendt i Heidegger. Pedagogiczna obietnica filozofii, Wydawnictwo Universitetas, Kraków 2015.

Suchodolski B., Pedagogika, [w:] Encyklopedia pedagogiczna, red. W. Pomykało, Fundacja Innowacja, Warszawa 1993.

Szołtysek A.E., Filozofia wychowania: ontologia, metafizyka, antropologa, aksjologia, Wydawnictwo Adam Marszałek, Torun 1998.

Turner V., Proces rytualny. Struktura i antystruktura, przekł. E. Dżiurak, Wydawnictwo Naukowe PWN, Warszawa 2010.

Waligóra M., Wstęp do fenomenologii, Wydawnictwo Universitas, Kraków 2013.

Wander M., Dzienniki i listy, przekł. M. Skalska, Wydawnictwo Poznańskie, Poznań 1987.

Wygotski L.S., Wybrane prace psychologiczne, przekł. E. Flesznerowa, J. Fleszner, PWN, Warszawa 1971.

Wygotski L.S., Wybrane prace psychologiczne. Dzieciństwo i dorastanie II, przekł. A. Brzezińska i in., Zysk i S-ka Wydawnictwo, Poznań 2002. 